\title{
Growth and Production of Cultivars Ornamental Sunflower Irrigated With Water of Different Salinities
}

\author{
Samanda Costa Santos ${ }^{1}$, Amaralina Celoto Guerrero ${ }^{2}$, Adriana Silva Lima ${ }^{2}$, Reynaldo Teodoro de Fatima ${ }^{3}$, \\ Janiny Vieira Abrantes ${ }^{1}$, Marcos Eric Barbosa Brito ${ }^{4}$, Arthur Vinicius Felinto Fernandes ${ }^{2}$ \\ $\&$ Eder Pereira da Rocha Sousa ${ }^{2}$ \\ ${ }^{1}$ Programa de Pós-graduação em Sistemas Agroindustriais, Universidade Federal de Campina Grande, Paraiba, \\ Brazil \\ ${ }^{2}$ CCTA, Universidade Federal de Campina Grande, Pombal, Paraiba, Brazil \\ ${ }^{3}$ Programa de Pós-graduação em Agronomia, Universidade Federal da Paraíba, Paraiba, Brazil \\ ${ }^{4}$ Universidade Federal de Sergipe, Campus do Sertão, Sergipe, Brazil \\ Correspondence: Reynaldo Teodoro de Fatima, Programa de Pós-graduação em Agronomia, Universidade \\ Federal da Paraíba, Paraiba, Brazil. E-mail: reynaldo.t16@gmail.com
}

Received: July 3, $2018 \quad$ Accepted: August 4, $2018 \quad$ Online Published: September 15, 2018

doi:10.5539/jas.v10n10p378 URL: https://doi.org/10.5539/jas.v10n10p378

\begin{abstract}
The sunflower (Helianthus annuus L.) appears as an income alternative to the producers of the northeastern region of Brazil, however limited by the salinity present in the waters of the region, which makes it necessary to select cultivars that are more adaptable to this situation. On this, the objective was assessing the development of two cultivars of cutting ornamental sunflower with waters of different salinities. The experiment was performed in conditions of protected environment at UFCG, CCTA-Pombal-PB. It was performed in outline of blocks in factorial scheme $5 \times 2$, being five saline levels $(\mathrm{N} 1=0.3$, supply water; $\mathrm{N} 2=1.5 ; \mathrm{N} 3=2.7 ; \mathrm{N} 4=3.9$; and $\mathrm{N} 5=$ $5.1 \mathrm{dS} \mathrm{m}^{-1}$ ) and two cutting ornamental sunflower cultivars (Red Sun and Vincents II), with four repetitions and two plants by portion, with a total of 80 experimental units. The irrigation water salinity affected all the analyzed variables, up to estimate level of $2.7 \mathrm{dS} \mathrm{m}^{-1}$ acceptable reductions happen of $10 \%$ in the inflorescence and stem of cultivars of ornamental sunflower. The Red Sun cultivar when compared with cultivar Vincents II demonstrated better results in the studied variables.
\end{abstract}

Keywords: floriculture, Helianthus annuus L., saline stress

\section{Introduction}

The sunflower (Helianthus annuus L.) is a yearly dicotyledonous plant originated in the north American continent that, due to its high adaptation to edafoclimatic conditions has been gaining prominence in the Brazilian agribusiness (Caldeira et al., 2017). This fact was associated mainly to the most various purposes of cultivation: from grains production to oil extraction and animal feeding, as in the production of cutting flowers and vase (Brito et al., 2017). Flower and plant trade has been consolidating as economic activity relevant in all national territory, mainly by the decentralization off the South of the country, being produced by big and small owners (Junqueira \& Peetz, 2014).

As a way to follow up the development of this sector, it comes as an alternative the cultivation of cutting ornamental sunflower that, besides the high adaptation to the environment conditions, present short cycle and inflorescences lush leading to a high acceptance by consumers, mainly for production of arrangements and decorations (Andrade et al., 2017). This situation makes these cultivars an alternative to the socioeconomic development of the northeastern region of Brazil.

As main barrier to the sector development in this region is the restriction of good quality water for irrigation, leading producers to adopt water resources with high concentration of salts (Silva et al., 2015). This condition leads to a reduction of the soil water potential, leading to a decrease of absorption of water by the plant, and therefore, the nutritional unbalance, by the accumulation of ions as $\mathrm{Na}^{+}$and $\mathrm{Cl}^{-}$, that over time provide a toxic effect leading to restrictions of plant metabolism (Souza et al., 2017; Zhang et al., 2017). 
Thus, the use of saline Waters for irrigation for plant production is a challenge that has been overcome in different parts of the world through the adoption of adequate practices of culture handling of soil and water (Medeiros et al., 2017), amongst them, we highlight the use of plants tolerant to salinity and sodicity (Brito et al., 2015). For Pivetta et al. (2012), the success of production of certain culture starts with the choice of a cultivar adapted to the region conditions, thus, studies that assess the agronomic development of culture when subject to the environment conditions of cultivation place are necessary.

In view of this, the objective was to assess the development of two cultivars of cutting ornamental sunflower irrigated with waters of different salinities.

\section{Method}

\subsection{Location and Description of Experiment Area}

The experimented was performed in conditions of protected environment, vegetation house at Universidade Federal de Campina Grande, Center of Science and Agrifood Technology of Pombal Campus-PB, located at $6^{\circ} 47^{\prime} 3.87^{\prime \prime} \mathrm{S}$ and $37^{\circ} 48^{\prime} 5.75^{\prime \prime} \mathrm{W}$, with average altitude of 170 meters, from November 2017 to February 2018. The climate according to the Köppen classification is type Aw, hot and damp with summer and fall rains and yearly average rainfall of $800 \mathrm{~mm}$ (Moura et al., 2011).

\subsection{Description of Handling}

The experiment was performed in outlining of block (DBC), presenting a factorial scheme of $2 \times 5$, two cultivars of cutting ornamental sunflower (red Sun and Vincents II), and five levels of irrigation water salinity (ECw) $(0.3$; $1.5 ; 2.7 ; 3.9$ and $5.1 \mathrm{dS} \mathrm{m}^{-1}$ ), with four repetitions and two plants by portion, with a total of 80 experimental units. The solutions were obtained through addition of sodium chloride $(\mathrm{NaCl})$ and local supply water $\left(0.3 \mathrm{dS} \mathrm{m}^{-1}\right)$.

The used cultivars presented characteristics of height from 1 to 3 meters, vigorous and of early cycle, hairy leaves, different in color: a red one with dark core (Red sun) and a yellow one with dark core (Vincents II).

\subsection{Setup and Experiment Steps}

Plastic Vases with capacity of 15 liters were used, with holes in the base for free drainage, filled with $0.8 \mathrm{~kg}$ of gravel, which covered the base of the vase and followed by $14.2 \mathrm{~kg}$ soil material provided from UFCG campus in Pombal-PB. Before seeding, a volume of water necessary for the soil to reach field capacity, through a saturation method by capillarity followed by free drainage.

The physicochemical characteristics of the soil used (Table 1) were determined by the method described by Texeira et al. (2017) at Universidade Federal da Paraíba (UFPB), Center of Agro Science, Campus II Areia, PB, Soil Science department.

Table 1. Physicochemical Characteristics of the substrate used in the experiment

\begin{tabular}{|c|c|c|c|c|c|c|c|c|c|}
\hline \multicolumn{10}{|c|}{ Chemical Features } \\
\hline $\mathrm{pH}$ & $\mathrm{P}$ & $\mathrm{K}^{+}$ & $\mathrm{Na}^{+}$ & $\mathrm{Ca}^{2+}$ & $\mathrm{Mg}^{2+}$ & SB & CTC & $\mathrm{Al}^{3+}$ & $\mathrm{H}+\mathrm{Al}^{3+}$ \\
\hline $\mathrm{CaCl}_{2} 1: 2.5$ & $\mathrm{mg} \mathrm{dm}^{-3}$ & -------- & ----- & - & ------ & $\mathrm{d} / \mathrm{dm}^{3}$ & -1----. & ----- & - \\
\hline 6.5 & 536.6 & 143.67 & 0.07 & 1.20 & 0.71 & 2.34 & 3.15 & 0.10 & 0.81 \\
\hline \multicolumn{10}{|c|}{ Physical Features } \\
\hline $\mathrm{MO}$ & & Sand & & Silt & & Clay & \multicolumn{3}{|c|}{ Texture Class } \\
\hline \multicolumn{10}{|l|}{-----} \\
\hline 4.79 & & 851 & & 99 & & 50 & \multicolumn{3}{|c|}{ Free Sand } \\
\hline
\end{tabular}

Note. pH: hydrogen potential; $\mathrm{Ca}^{2+}$ and $\mathrm{Mg}^{2+}$ extracted with $1 \mathrm{M} \mathrm{KCl}$ at $\mathrm{pH} 7.0 ; \mathrm{Na}^{+}$and $\mathrm{K}^{+}$extracted using $1 \mathrm{M}$ $\mathrm{NH}_{4} \mathrm{OAc}$ at $\mathrm{pH} 7.0 ; \mathrm{Al}^{3+}+\mathrm{H}^{+}$extracted using $0.5 \mathrm{M} \mathrm{CaOAc} \mathrm{pH}$ 7.0.

Seeding was performed in plastic cups of $100 \mathrm{~mL}$, one seed per recipient, 7 days after germination when they presented two final leaves; they were transplanted to the $15 \mathrm{~L}$ vases, at the end of the afternoon.

On day 30 after the transplantation (DAT), the plants were tutored and fertilized with macro and micro nutrients $\left(\mathrm{N}, \mathrm{P}_{2} \mathrm{O}_{5}, \mathrm{~K}_{2} \mathrm{O}, \mathrm{Ca}, \mathrm{Mg}, \mathrm{S}, \mathrm{B}, \mathrm{Co}, \mathrm{Cu}, \mathrm{Fe}, \mathrm{Mn}, \mathrm{Mo}, \mathrm{Zn}\right.$ ), via leaf, following the specific need for cultivation (Sfredo et al., 1984).

The application of saline water started at 30 DAT, with daily manual irrigations, the applied volume was determined by the lysimetric process of drainage, calculated in function of the applied water volume drained from previous irrigation (Bernardo et al., 2006). 
Every 15 days, a $10 \%$ leaching fraction was applied based on the volume applied in this period, which purpose was to reduce the accumulation of substrate salts.

During the experiment, the following cultivation handling was performed: manual elimination of spontaneous plants and weekly scarification before each soil irrigation.

\subsection{Assessed Variables}

In order to assess the effect of treatments over the plants growth, the absolute growth rate (AGR) for plants height $\left(\mathrm{AGR}_{\mathrm{PH}}\right)$ and stem diameter $\left(\mathrm{AGR}_{\mathrm{SD}}\right)$ were measured from 15 to $60 \mathrm{DAT}$. The determination of absolute growth rate (TCA) and relative growth rate was obtained employing the method proposed by Benicasa (2003), as described in the Equations 1 and 2, respectively:

$$
\mathrm{TCA}=(\mathrm{A} 2-\mathrm{A} 1) /(\mathrm{t} 2-\mathrm{t} 1)
$$

where, $\mathrm{AGR}=$ Absolute Growth Rate; $\mathrm{A} 2=$ plant growth at time $\mathrm{t} 2 ; \mathrm{A} 1=$ plant growth at time $\mathrm{t} 1 ; \mathrm{t} 2-\mathrm{t} 1=$ difference of time between samples

The relative growth rate was obtained by Equation 2, in which it was measured the growth in function of preexisting matter, adapting to plants height and diameter.

$$
\mathrm{TCR}=(\ln \mathrm{A} 2-\ln \mathrm{A} 1) /(\mathrm{t} 2-\mathrm{t} 1)
$$

where, $\mathrm{RGR}=$ relative growth rate; $\mathrm{A} 2=$ plant growth at time $\mathrm{t} 2 ; \mathrm{A} 1=$ plant growth at time $\mathrm{t} 1, \mathrm{t} 2-\mathrm{t} 1=$ difference of time between samples and; $\ln =$ natural logarithm.

The determination of phytomass was performed at 60 DAT through a destructive assessment of the experiment, the plants were collected, washed (the roots), and then fractioned in leaf, steam, inflorescence and root. Later, the material was conditioned in paper bags previously identified and put in an air circulation greenhouse at $65^{\circ} \mathrm{C}$ for 48 hours. After obtaining the constant weight, the determination of dried phytomass leaves (LDP), inflorescences (IDP), roots (RDP) and stem dried phytomass (SDP), besides the dried phytomass of above-ground (ADP) (LDP+IDP+SDP), and total dried phytomass (TDP) (ADP + RDP) on a precision scale of $0.01 \mathrm{~g}$.

\subsection{Statistics Analysis}

The variables were assessed through variance analysis by $\mathrm{F}$ test and, in the cases of significative effect, performed the analysis of linear and quadratic polynomial regression for water conductivity $\left(\mathrm{dS} \mathrm{m}^{-1}\right)$, and conclusive for acultivars of ornamental cut of sunflower, using the statistics software SISVAR (Ferreira, 2014). The choice of regression was performed through better adjustment based on the coefficient of determination $\left(\mathrm{R}^{2}\right)$ and taking in to account a probable biological explanation.

\section{Results e Discussion}

According to the summary of variance analysis (Table 2), it is verified the significative effect in the interaction between electrical conductivity of irrigation water and cultivars of sunflower over the plant absolute growth rate $\left(\mathrm{AGR}_{\mathrm{PH}}\right)$ in the period of 15-60 DAT. While the other growth rated had a significative effect for irrigation water salinity and cultivars of sunflower, in isolation.

Table 2. Summary of variance analysis for absolute $\left(\mathrm{AGR}_{\mathrm{PH}}\right)$ and relative $\left(\mathrm{RGR}_{\mathrm{PH}}\right)$ growth rates of plant height and absolute $\left(\mathrm{AGR}_{\mathrm{SD}}\right)$ and relative $\left(\mathrm{RGR}_{\mathrm{SD}}\right)$ growth of plant of stem diameter, for two cultivars of cutting ornamental sunflower irrigated with saline waters in the period 15-60 DAT

\begin{tabular}{llllll}
\hline \multirow{2}{*}{ Variation Resource } & \multicolumn{5}{c}{ Average Square } \\
\cline { 2 - 6 } & $\mathrm{GL}$ & $\mathrm{AGR}_{\mathrm{PH}} 15-60$ & $\mathrm{RGR}_{\mathrm{PH}} 15-60$ & $\mathrm{AGR}_{\mathrm{SD}} 15-60$ & $\mathrm{RGR}_{\mathrm{SD}} 15-60$ \\
\hline Cultivars (C) & 1 & $2.36^{* *}$ & $0.001^{* *}$ & $0.002^{* *}$ & $0.0000^{* *}$ \\
Saline levels (S) & 4 & $0.22^{* *}$ & $0.0000^{* *}$ & $0.001^{* *}$ & $0.0000^{* *}$ \\
$\quad$ Linear regression & 1 & $0.75^{* *}$ & $0.0000^{\mathrm{ns}}$ & $0.002^{* *}$ & $0.0000^{*}$ \\
$\quad$ Quadratic regression & 1 & $0.096^{\mathrm{ns}}$ & $0.0000^{* *}$ & $0.0000^{\mathrm{ns}}$ & $0.0000^{\mathrm{ns}}$ \\
Interaction (C $\times \mathrm{S})$ & 4 & $0.087^{*}$ & $0.0000^{\mathrm{ns}}$ & $0.0000^{\mathrm{ns}}$ & $0.0000^{\mathrm{ns}}$ \\
Blocks & 3 & $0.046^{\mathrm{ns}}$ & $0.0000^{\mathrm{ns}}$ & $0.0000^{\mathrm{ns}}$ & $0.0000^{\mathrm{ns}}$ \\
CV $(\%)$ & - & 9.58 & 7.93 & 15.63 & 12.68 \\
\hline Note. & ns $, * *, *$ respectively not significant, significative to $1 \%$ and $5 \%$ & &
\end{tabular}


The increase of irrigation water salinity exerted negative effect over the absolute growth rate of plant height $\left(\mathrm{AGR}_{\mathrm{PH}}\right)$ in which, according to linear regression equation (Figure 1), it is observed unit reductions of $4.48 \%$ and $6.62 \%$ for unit increase in ECw in the cultivars of cutting ornamental sunflower Vincents II and Red Sun, respectively. Leading to $\mathrm{ECW}$ of irrigation of $5.1 \mathrm{dS} \mathrm{m} \mathrm{m}^{-1}$ depreciations of $21.52 \%$ in cultivar Vincent II and $31.76 \%$ in cultivar Red Sun, when compared to $\mathrm{ECW}$ of $0.3 \mathrm{dS} \mathrm{m}^{-1}$. Even presenting greater losses in this variable, Red Sun cultivar presented better results in $\mathrm{AGR}_{\mathrm{PH}}$ when compared to cultivar Vincents II. It is noted that the inhibition of plant growth by salinity happened as the excess of salts in the soil solution changes the metabolic activities of cells in the process of cell stretching, restricting the elasticity of cell wall, reducing the cell stretching and, as consequence, the plant growth (Taiz et al., 2017).

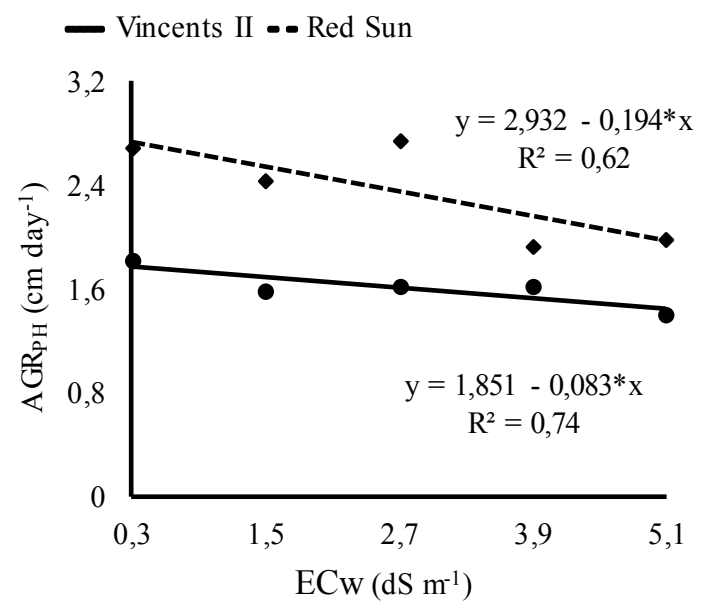

Figure 1. Interaction of two cultivars of cutting ornamental sunflower in function to the saline levels of irrigation water under the absolute growth rate of plant height $\left(\mathrm{AGR}_{\mathrm{PH}}\right)$ in the period 15-60 DAT

The relative growth rate of plant height $\left(\mathrm{RGR}_{\mathrm{PH}}\right)$ was adjusted to the quadratic model (Figure $\left.2 \mathrm{~A}\right)$, it was noted the increase of $8.11 \%$ when the plants were irrigated with ECW water of $2.7 \mathrm{dS} \mathrm{m}^{-1}$, when compared to salinity of $0.3 \mathrm{dS} \mathrm{m} \mathrm{m}^{-1}$. This situation shows a certain tolerance of sunflower plants to irrigation water salinity, may be related to compartmentalization of salts in the interior of the vacuoles (Willadino \& Camara, 2010).
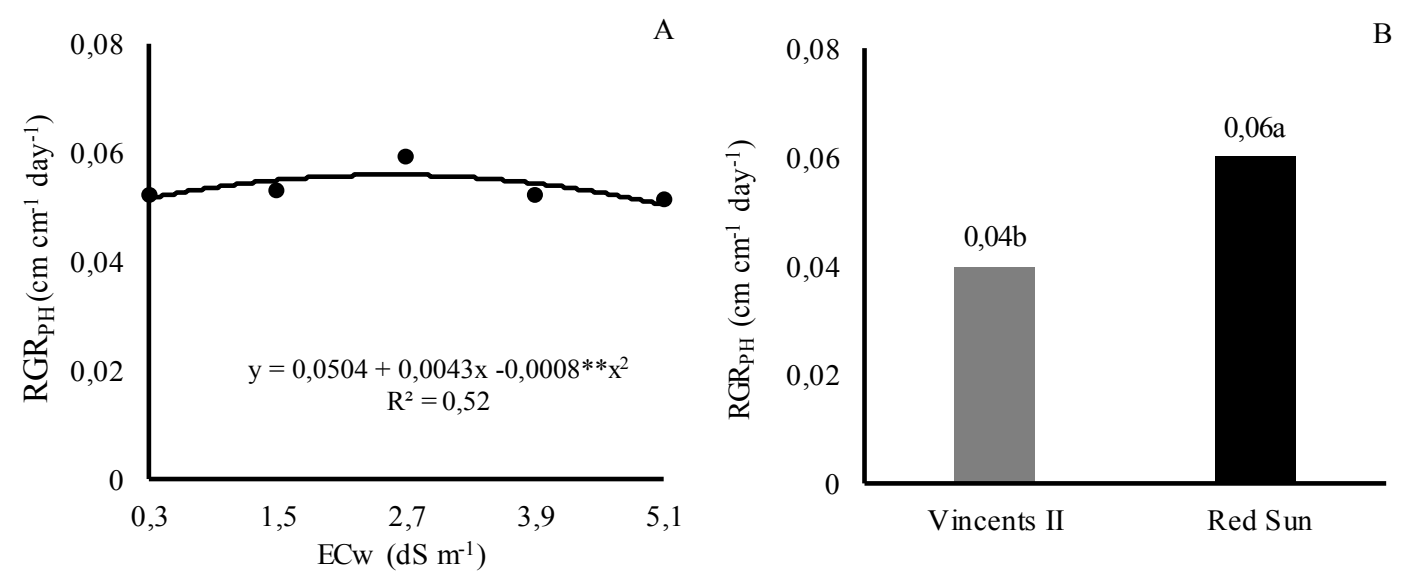

Figure 2. Isolated effect factors to saline levels of irrigation water (A) and of two cultivars cutting ornamental sunflower $(B)$ under the relative growth rate of plant height $\left(\mathrm{RGR}_{\mathrm{PH}}\right)$ in the period 15-60 DAT

The cultivar of cutting ornamental sunflower Red Sun was superior, when compared to cultivar Vincents II (Figure 2B), showing a growth of $33.3 \%$ in the plants height. This behavior may be related to a better use of 
environment conditions by plants with increase of material along the development stage of cultivation cycle (Lustri et al., 2017).

As regards absolute growth rate for stem diameter (Figure 3A), the additions of irrigation water salinity result in linear reductions of $\mathrm{AGR}_{\mathrm{SD}}$ of $5.77 \%$ in each $\mathrm{ECW}$ unit increase, leading to a total reduction of $27.7 \%$ when compared to salinity of 5.1 with the $0.3 \mathrm{dS} \mathrm{m}^{-1}$. Torres et al. (2014) attributed such reduction to energy consumption for organic compounds synthesis osmotically active, and necessary for processes of compartmentalization in the regulation of ions transportation.
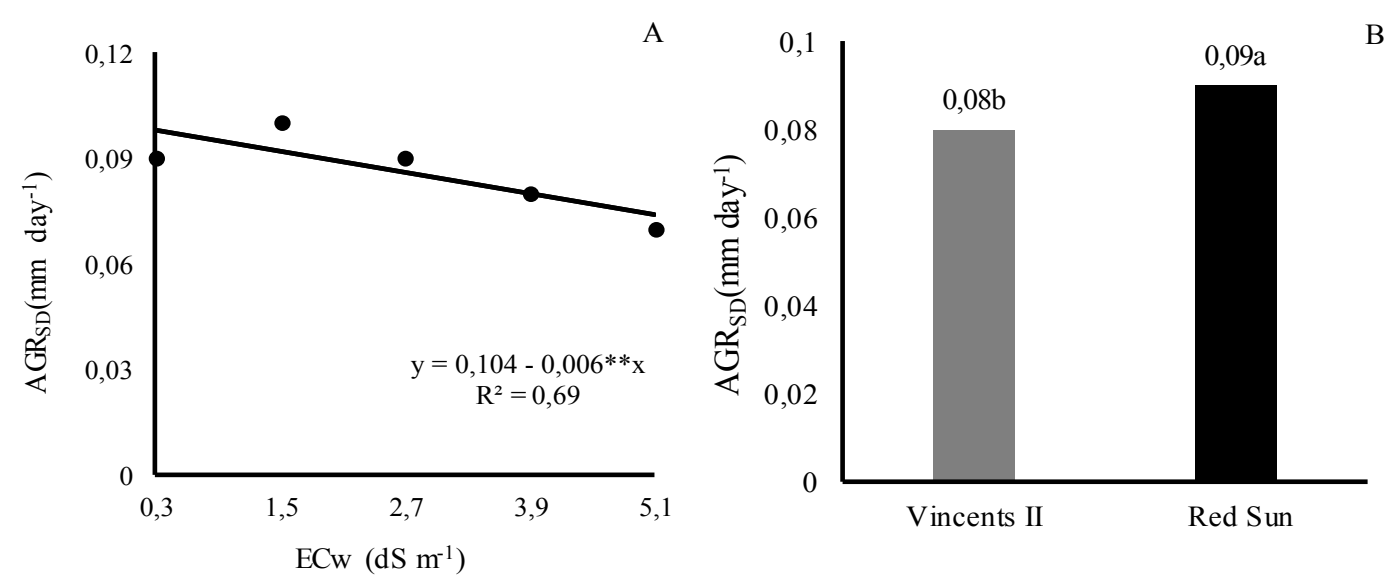

Figure 3. Isolated effect factors to saline levels of irrigation water (A) and of two cultivars cutting ornamental sunflower (B) under the absolute growth rate of stem diameter (AGRSD) in the period of 15-60 DAT

The cultivar of cutting ornamental sunflower Red Sun showed superiority when compared to cultivar Vincents II (Figure 3B), presented increase of $11.1 \%$ in $\mathrm{AGR}_{\mathrm{SD}}$. A possible explanation for this fact would be that such cultivar could keep the increase in the concentration of $\mathrm{CO}_{2}$, which led to increase of plant photosynthetic rated (Gomes et al., 2018).

In relation to relative growth rate of steam diameter, it was noted that it would present similar behavior to TCAdh, where the second model of linear regression (Figure 4A) showed decrease of $8.18 \%$ by unit increase of electrical conductivity of irrigation water, reaching saline level of $5.1 \mathrm{dS} \mathrm{m}^{-1}$, leading to a decrease of $39.26 \%$ in $\operatorname{RGR}_{\mathrm{SD}}$ compared to plants irrigated with local supply water $\left(0.3 \mathrm{dS} \mathrm{m}^{-1}\right)$. According to Freire et al. (2010), it causes damages to pressure of turgescence in the cells due to decrease of water content in the tissues, resulting in decrease of cell wall expansion, causing lower growth in the plants.

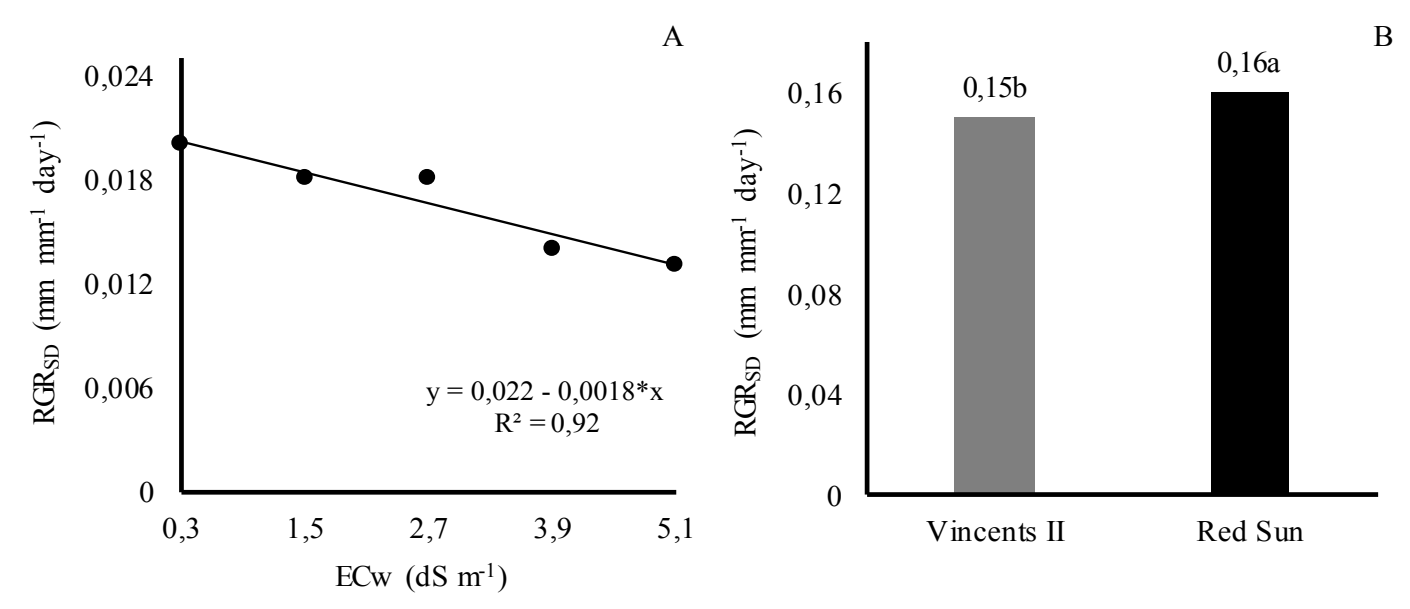

Figure 4. Isolated effect factors to saline levels of irrigation water (A) and of two cultivars cutting ornamental sunflower (B) under the relative growth rate of plant height (RGRSD) in the period of 15-60 DAT 
The cultivar of cutting ornamental sunflower Red Sun continued superior when compared to cultivar Vincent II (Figure 4B), showing an increase of $6.25 \%$ in the diameter relative growth rate. Certainly, this advantage in relation to Vincents II is due to better vegetal material characteristics, and as it is a hybrid, consequently, it presented better force, due to heterozygous.

In Table 3, it is noted significative effect of cultivars isolated factors of cutting ornamental sunflower and saline levels of irrigation water over the phytomass variables of leaves (LDP), inflorescence (IDP), above-ground (ADP) and total (TDP). It is also noted the effect of factors interaction for stem dried phytomass variables (SDP) and roots $(\mathrm{RDP})$.

Table 3. Summary of variance analysis for variables of dry phytomass of leaves (LDP), inflorescence (IDP), roots (RDP), stem (SDP), and for dry phytomass above-ground (ADP) and total (TDP), for two cultivars of cutting ornamental sunflower irrigated with saline waters

\begin{tabular}{llllllll}
\hline \multirow{2}{*}{ Variation Resource } & \multicolumn{7}{c}{ Average Square } \\
\cline { 2 - 7 } & GL & LDP & IDP & RDP & SDP & ADP & TDP \\
\hline Cultivars (C) & 1 & $7.25^{* *}$ & $7.77^{*}$ & $0.54^{\mathrm{ns}}$ & $64.36^{* *}$ & $1099.03^{* *}$ & $103.97^{* *}$ \\
Saline levels (S) & 4 & $6.76^{* *}$ & $7.54^{* *}$ & $1.78^{* *}$ & $38.42^{* *}$ & $1228.30^{* *}$ & $138.01^{* *}$ \\
$\quad$ Linear regression & 1 & $9.41^{* *}$ & $9.58^{*}$ & $3.71^{* *}$ & $134.65^{* *}$ & $3442.03^{* *}$ & $333.58^{* *}$ \\
$\quad$ Quadratic regression & 1 & $3.55^{*}$ & $0.01^{\mathrm{ns}}$ & $0.14^{\mathrm{ns}}$ & $2.52^{\mathrm{ns}}$ & $192.54^{\mathrm{ns}}$ & $3.38^{\mathrm{ns}}$ \\
Interaction (C x S) & 4 & $1.91^{\mathrm{ns}}$ & $3.84^{\mathrm{ns}}$ & $0.58^{*}$ & $13.37^{*}$ & $269.05^{\mathrm{ns}}$ & $25.91^{\mathrm{ns}}$ \\
Blocks & 3 & $0.09^{\mathrm{ns}}$ & $0.36^{\mathrm{ns}}$ & $0.21^{\mathrm{ns}}$ & $0.76^{\mathrm{ns}}$ & $63.33^{\mathrm{ns}}$ & $10.98^{\mathrm{ns}}$ \\
CV(\%) & - & 14.19 & 22.69 & 15.67 & 18.06 & 11.16 & 14.46 \\
\hline
\end{tabular}

Note. ${ }^{\text {ns }},{ }^{* *}, *$ respectively not significative, significative to $\mathrm{p}<0.01$ and $\mathrm{p}<0.05$.

Irrigation water provided quadratic behavior of leaves dry phytomass (Figure 5A), with accented reductions from the ECw of $2 \mathrm{dS} \mathrm{m}^{-1}$. Up to this level, there was an increase of $21 \%$ in FSF, when compared to plants irrigated with supply water $\left(0.3 \mathrm{dS} \mathrm{m}^{-1}\right)$. It is associated with strategies to reduce the effect of salinity by the plant, with accumulation of different types of organic substances and inorganic myocytes in the cytosol in response to stress by salts, as a form of regulation of cell processes (Khan et al., 2014).
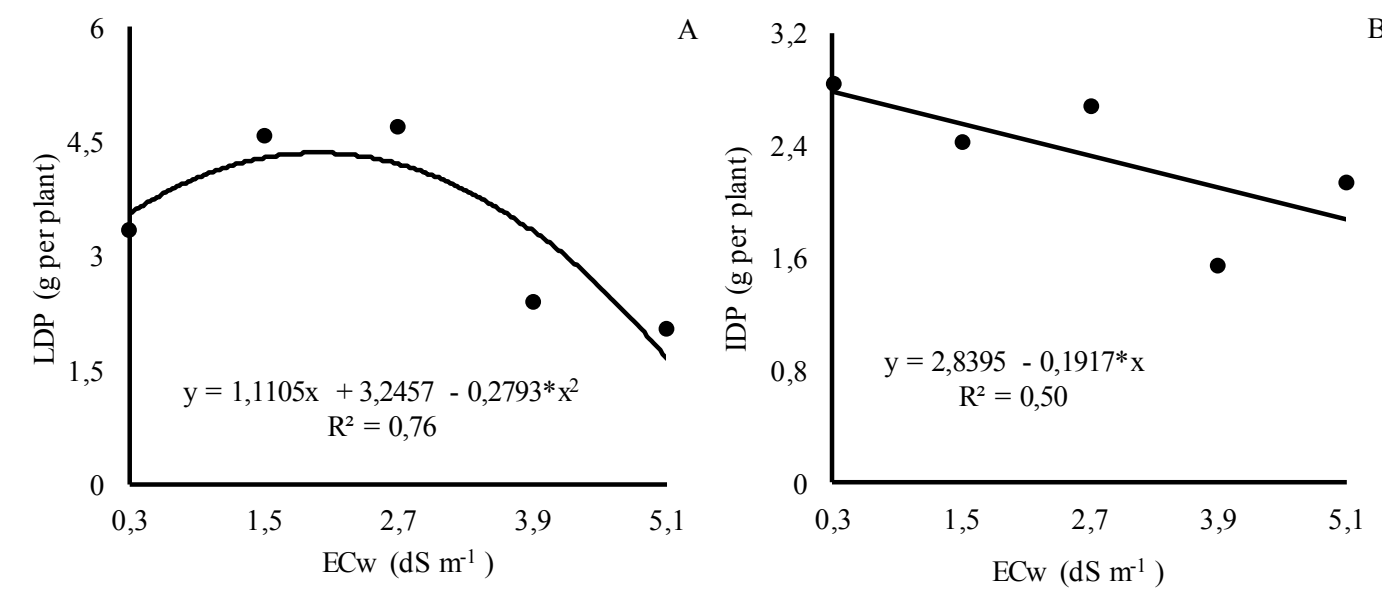

Figure 5. Dried Phytomass of leaves-LDP (A) and inflorescence-IDP (B) of two cultivars of cutting ornamental sunflower, under different saline levels of irrigation waters

The increase of irrigation water salinity significantly affected $(\mathrm{p}<0.05)$ the production of dried phytomass of inflorescence (DPI) for factor isolated, and according to regression equation (Figure 5B), it was noted that the model which the data better adjusted was the linear, decrease of $6.75 \%$ with unit increase of ECw of irrigation, and reaching a total reduction of $32.4 \%$ in $\mathrm{ECw}$ of $5.1 \mathrm{dS} \mathrm{m}^{-1}$ compared to $0.3 \mathrm{dS} \mathrm{m}^{-1}$. Fact explained by 
nutritional unbalance in the plants subject to salinity, which limits the translocation of nutrients for inflorescence, decreasing the development (Souza et al., 2017).

The increase of salinity of irrigation water exerted negative effect over the dried phytomass of roots, in which, according to linear regression equation (Figure 6A), resulting in unit reductions of $12.03 \%$ and $15.03 \%$ for cultivars of cutting ornamental sunflower Vincents II and Red Sun, respectively. It happened in the ECw of irrigation of $5.1 \mathrm{dS} \mathrm{m}^{-1}$ a total decrease of 57.74 in cultivar Vincents II and $72.14 \%$ in cultivar Red Sun when compared to $\mathrm{ECW}$ of $0.3 \mathrm{dS} \mathrm{m}{ }^{-1}$. Consequence of the stomatal closing and reduction in the speed of leaf elongation which limits the supply of photo-assimilates for root system, decreasing the formation of new roots and root growth (Kawavata et al., 2017).
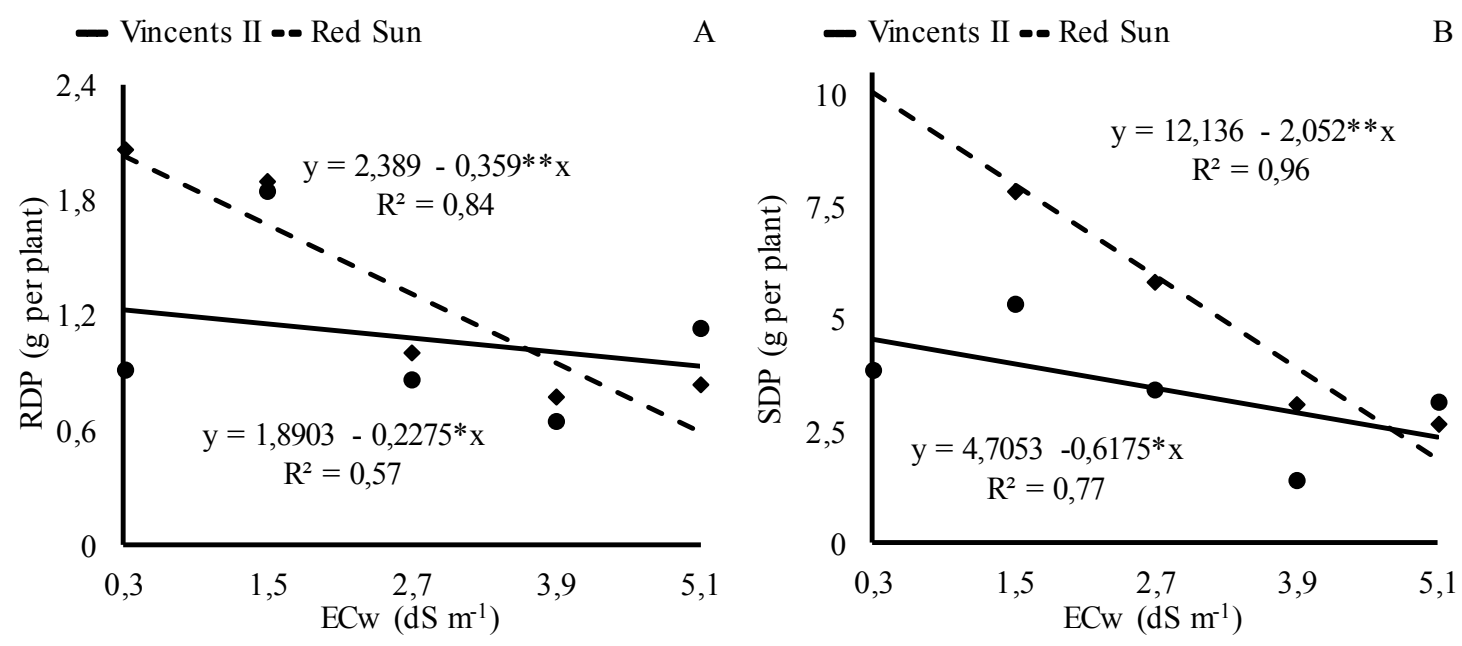

Figure 6. Interaction of two cultivars of cutting ornamental sunflower (Helianthus annuus L.), in function of saline levels of irrigation water under the dried phytomass of roots (RDP) and stems (SDP) of the plant

In relation to stem dried phytomass, the high level of salinity in the irrigation water exerted negative effect over this variable, where, according to linear regression equation (Figure 6B), presented a decrease of $13.12 \%$ to $16.90 \%$ for cultivars of cutting ornamental sunflower Vincent II and Red Sun, respectively. It caused decreases of $62.97 \%$ on $\mathrm{ECW}$ irrigation of $5.1 \mathrm{dS} \mathrm{m}^{-1}$ on cultivar Vincent II and $81.16 \%$ on Red Sun, when compared to ECw $0.3 \mathrm{dS} \mathrm{m}^{-1}$. Willadino and Camara (2010) assign this reduction to osmotic, toxic and nutritional effects arising from the accumulation of salts in the root zone of the plant.

The phytomass of air part (Figure 7A), the data adjusted to a decreasing linear relation, for dried phytomass of above-ground reduced in $13.00 \%$ for unit increase of electrical conductivity of irrigation water (ECw), total reduction of $62.33 \%$ in the air part, when compared to higher and lower saline level $\left(0.3 \mathrm{dS} \mathrm{m}^{-1}\right.$ and $\left.5.1 \mathrm{dS} \mathrm{m}^{-1}\right)$. Travassos et al. (2011), in research of aquarium of irrigated sunflower with brackish water, obtained a dried phytomass variable of above-ground, decreases of $13.56 \%$ for unit increase of electrical conductivity of irrigation water. 

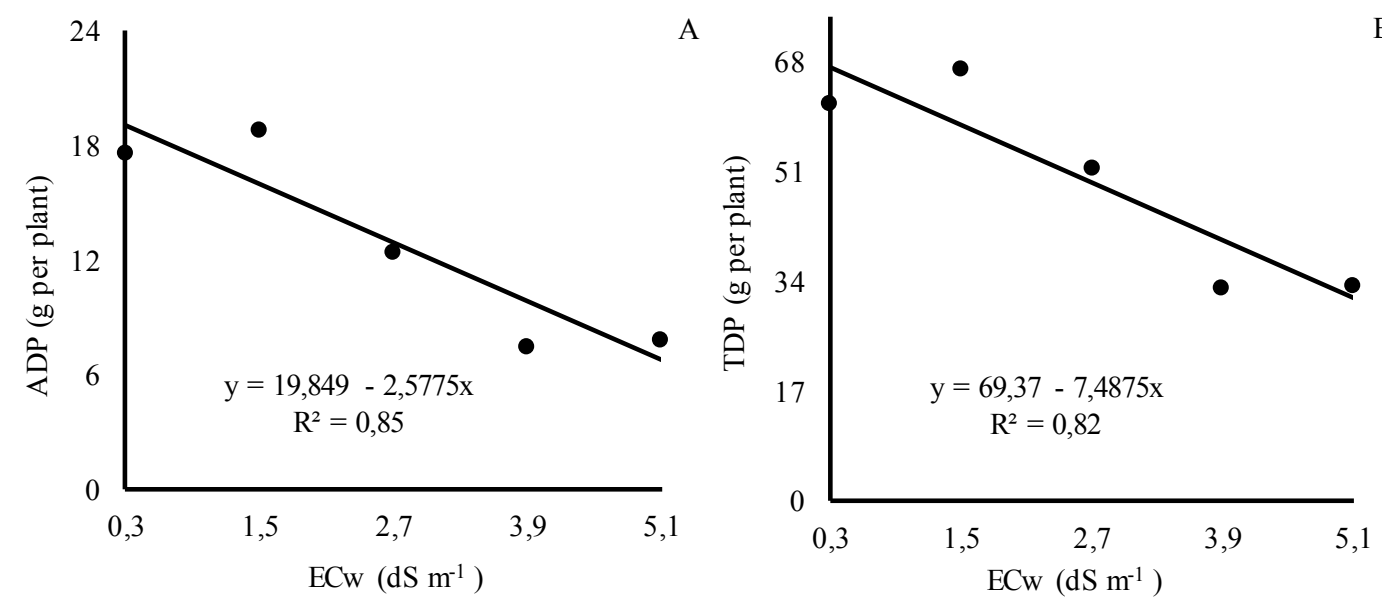

Figure 7. Isolated effect of conductivity of irrigation water in the dried phytomass of above-ground-ADP (A) and total-TDP (B) under two cultivars of cutting ornamental sunflower

While for total dried phytomass (Figure 7B), presented similar behavior to ADP, presenting a reduction of 10.8\% by unit increase in the $\mathrm{ECw}$, resulting in a total reduction of $51.8 \%$ in total phytomass, when compared to higher saline level $\left(5.1 \mathrm{dS} \mathrm{m}^{-1}\right)$. According to Taiz et al. (2017), the decrease of TDP by increasing the salinity may be associated with inefficiency of roots in preventing the excessive accumulation of $\mathrm{Na}^{+}$and $\mathrm{Cl}^{-}$in the air part, where the accumulation of them affect the activity of several enzymes, causing quantity and quality changes in the plant metabolism, resulting in low production of energy, besides causing disturbances in the assimilation of $\mathrm{N}$ and protein metabolism, reflecting in the reduction of TDP production.

Assessing the cultivars of sunflower isolated (Figure 8), it was noted that the Red Sun was superior in relation to variables analyzed compared to Vincents II. Presenting increase of $25.21 \%$ for dried phytomass of leaves, $28.11 \%$ dried phytomass of inflorescence, $25.05 \%$ for dried phytomass of above-ground (stem and leaves) and $21.33 \%$ of total dried phytomass of plants.

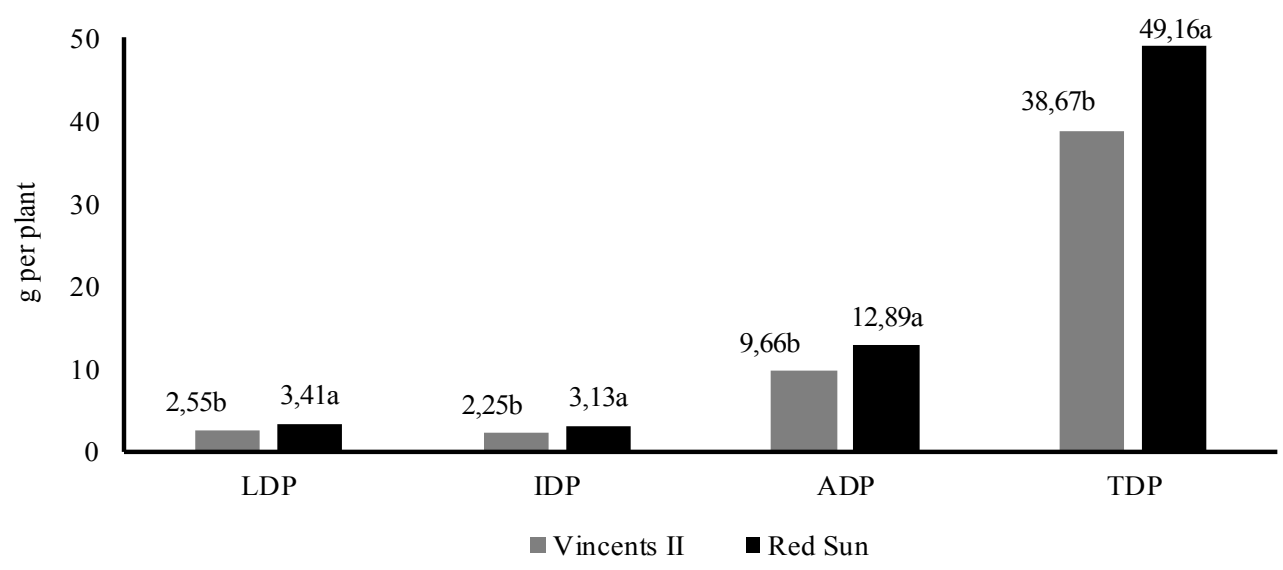

Figure 8. Isolated effect of two cultivars of cutting ornamental sunflower under dried phytomass of leaf (LDP), inflorescence (IDP), above-ground (ADP), and total dried phytomass (TDP), in different levels of conductivity of irrigation water

A possible explanation for this happening may be related to the capacity of this cultivar to adapt better to present environment conditions, as well as an increase in the efficiency of water use, making the plants better use this resource, with lower hydric loss through perspiration (Travasso et al., 2012). 


\section{Conclusions}

The salinity of irrigation water affected all the analyzed variables, up to the estimate level of $2.7 \mathrm{dS} \mathrm{m}^{-1}$, acceptable reductions of $10 \%$ in the inflorescence and stems of cultivars of ornamental sunflower.

The cultivar Red Sun when compared to cultivar Vincents II showed better results in studied variables.

\section{References}

Andrade, L. O., Gheyi, H. R., da Silva Dias, N., Nobre, R. G., \& Dias, E. M. S. (2017). Teor de macronutrientes em girassol ornamental sob doses de esterco e efluente doméstico. Revista Verde de Agroecologia e Desenvolvimento Sustentável, 12(3), 607-611. https://doi.org/10.18378/rvads.v12i3.4659

Benincasa, M. M. P. (2003). Análise de crescimento de plantas, noções básicas (2nd ed., p. 41). Jaboticabal: FUNEP.

Bernardo, S., Soares, A. A., \& Mantovani, E. C. (2006). Manual de irrigação (8th ed., p. 625). Viçosa: UFV.

Brito, C. L., Matsumoto, S. N., Santos, J. L., Gonçalves, D. N., \& Ribeiro, A. F. (2016). Efeito do paclobutrazol no desenvolvimento de plantas de girassol ornamental. Revista de Ciências Agrárias, 39(1), 153-160. https://doi.org/10.19084/RCA15044

Brito, K. Q. D., Nascimento, R., Santos, J. E. A., Silva, I. A. C., \& Junior, G. D. (2015). Componentes de produção de genótipos de feijão-caupi irrigados com água salina. Revista Verde de Agroecologia e Desenvolvimento Sustentável, 10(4), 01-05. https://doi.org/10.18378/rvads.v10i4.3620

Caldeira, C. M., Carvalho, M. L. M., Oliveira, J. A., Kataoka, V. Y., \& Freire, A. I. (2015). Reduced time for evaluation of the germination test for sunflower seeds. Journal of Seed Science, 37(1), 70-75. https://doi.org/ $10.1590 / 2317-1545 \mathrm{v} 37 \mathrm{n} 1139405$

Ferreira, D. F. (2014). Sisvar: A Guide for its Bootstrap procedures in multiple comparisons. Ciência e Agrotecnologia, 38(2), 109-112. https://doi.org/10.1590/S1413-70542014000200001

Freire, A. L. O., Saraiva, V. P., Miranda, J. R. P., \& De Flag, G. B. (2010). Crescimento, acúmulo de íons e produção de tomateiro irrigado com água salina. Semina: Ciências Agrárias, 31(1), 1133-1144. https://doi.org/10.5433/1679-0359.2010v31n4Sup1p1133

Gomes, K. R., Gomes de Sousa, G., Viana, T. V. A., Costa, F. R. B., Azevedo, B. M., \& Silva Sales, J. R. (2018). Influência da irrigação e da adubação com fertilizante orgânico e mineral na cultura do girassol. Revista Brasileira de Agricultura Irrigada, 12(2), 2529-2541. https://doi.org/10.7127/rbai.v12n200798

Junqueira, A. H., \& Peetz, M. D. S. (2014). O setor produtivo de flores e plantas ornamentais do Brasil, no período de 2008 a 2013: atualizações, balanços e perspectivas. Revista Brasileira de Horticultura Ornamental, 20(2), 115-120. https://doi.org/10.14295/rbho.v20i2.727

Kawavata, C. K. H., Fois, D. A. F., Coppo, J. C., \& Neto, A. A. (2017). Influência de doses e de duas fontes de potássio no sistema radicular do milho e na condutividade elétrica no solo. Investigación Agraria, 19(1), 28-34. https://doi.org/10.18004/investig.agrar.2017.junio.28-34

Khan, A., Iqbal, I., Ahmad, I., Nawaz, H., \& Nawaz, M. (2014). Role of proline to induce salinity tolerance in sunflower (Helianthus annus L.). Science Technology and Development, 33(2), 88-93. Retrieved from $\mathrm{http}: / /$ docsdrive.com/pdfs/std/std/2014/88-93.pdf

Lustri, E. A., Silva, B. T., Peruchi, D. R. E., Moura, I. A., \& Fluminhan, A. (2017). Avaliação do desempenho agronômico de cultivares de girassol (Helianthus annuus L.) no cultivo em safrinha na região Oeste Paulista. Periódico Eletrônico Fórum Ambiental da Alta Paulista, 13(1), 37-51. https://doi.org/10.17271/ 1980082713120171488

Medeiros, J. F., Terceiro Neto, C. P. C., Dias, N.S., Gheyi, H. R., Silva, M. V. T., \& Loiola, A. T. (2017). Salinidade e ph de um argissolo irrigado com água salina sob estratégias de manejo. Revista Brasileira de Agricultura Irrigada, 11(3), 1407. https://doi.org/10.7127/rbai.v11n300560

Moura, E. M., Righetto, A. M., \& Lima, R. R. M. (2011). Avaliação da disponibilidade hídrica e da demanda hídrica no trecho do Rio Piranhas-Açu entre os Açudes Coremas-Mãe D'água e Armando Ribeiro Gonçalves. Revista Brasileira de Recursos Hídricos, 16(4), 7-19. https://doi.org/10.21168/rbrh.v16n4.p7-19

Pivetta, L. G., Guimarães, V. F., Fioreze, S. L., Pivetta, L. A., \& Castoldi, G. (2012). Avaliação de híbridos de girassol e relação entre parâmetros produtivos e qualitativos. Revista Ciência Agronômica, 43(3), 561-568. Retrieved from http://ccarevista.ufc.br/seer/index.php/ccarevista/article/view/1430/719 
Sfredo, G. J., Campo, R. J., \& Sarruge, J. R. (1984). Girassol: nutricao mineral e adubação (p. 36). Londrina: Embrapa-CNPSo.

Silva, A. C. N., Carvalho, C. M., Oliveira, A. C. M., Feitosa, H. O., \& Silva, L. L. (2015). Initial growth of irrigated peanut BR1 with saline water. Applied Research \& Agrotechnology, 8(3), 37-44. https://doi.org/10.5935/ PAeT.V8.N3.04

Souza, M. C. M. R., Menezes, A. S., Costa, R. S., Amorim, A. V., \& Lacerda, C. F. (2017). Tolerância à salinidade e qualidade de mudas de noni sob diferentes ambientes e matéria orgânica. Revista Brasileira de Agricultura Irrigada, 11(7), 2052-2062. https://doi.org/10.7127/RBAI.V11N700682

Taiz, L., Zeiger, E., Møller, I. M., \& Murphy, A. (2017). Fisiologia e desenvolvimento vegetal (6th ed., p. 888). Porto Alegre: Artmed.

Teixeira, P. C., Donagemma, G. K., Fontana, A., \& Teixeira, W. G. (2017). Manual de Métodos de Análise de Solo (3rd ed., p. 575). Brasília, DF: Embrapa.

Torres, E. C. M., Oliveira Freire, J. L., Oliveira, J. L., Bandeira, L. B., Melo, D. A., \& da Silva, A. L. (2014). Biometria de mudas de cajueiro anão irrigadas com águas salinas e uso de atenuadores do estresse salino. Nativa, 2(2), 71-78. https://doi.org/10.14583/2318-7670.v02n02a03

Travassos, K. D., Gheyi, H. R., Soares, F. A. L., Barros, H. M. M., Silva Dias, N., Uyeda, C. A., \& Silva, F. V. (2012). Crescimento e desenvolvimento de variedades de girassol irrigado com água salina. Irriga, 1(1), 324-339. https://doi.org/10.15809/irriga.2012v1n01p324

Willadino, L., \& Camara, T. R. (2010). Tolerância das plantas à salinidade: Aspectos fisiológicos e bioquímicos. Enciclopédia Biosfera, 6(11), 1-23. Retrieved from http://www.conhecer.org.br/enciclop/2010c/tolerancia\% 20das\%20plantas.pdf

Zhang, Z., Wang, Q., Wang, H., Nie, S., \& Liang, Z. (2017). Effects of soil salinity on the content, composition, and ion binding capacity of glomalin-related soil protein (GRSP). Science of the Total Environment, 581, 657-665. https://doi.org/10.1016/j.scitotenv.2016.12.176

\section{Copyrights}

Copyright for this article is retained by the author (s), with first publication rights granted to the journal.

This is an open-access article distributed under the terms and conditions of the Creative Commons Attribution license (http://creativecommons.org/licenses/by/4.0/). 